\title{
We Other Fairies
}

\begin{abstract}
XAVIA PUBLIUS
The ontology of onstage characters has long been a concern of performance theory, but the stakes of this hauntological question for the characters themselves is rarely addressed. How and why do ethereal queer beings inhabit the stage, and how do they communicate with us (and each other)? As my writing wanders between critical theory and personal mourning, I diarize my journey through this question and the ways ritual and the carnivalesque function to bring forth these spirits onto our plane. These diary entries are edited, cut, and pasted into a more formal order as is the practice in academic writing, but the traces of that restructuring violence remain through use of caesurae ||CUT|| to indicate cuts and curly braces $\{. .$.$\} to indicate redaction.$ I play off of Michel Foucault's musings on "other Victorians" to demonstrate how the film Were the World Mine and plays such as A Midsummer Night's Dream; Zanna, Don't!; Shakespeare's REJJ; Three Mysterious Women; and Lenin's Embalmers illustrate the queer politics of trauma, memory, performance, and affect in ways that traditional Western methods of mourning and memorialization do not.
\end{abstract}

Keywords: queer theory, hauntology, Shakespeare, acting, diary, carnivalesque

\section{APRIL 2020}

$\mathrm{M}$

y grandmother died ten years ago today. While personally significant, this usually wouldn't be of theoretical importance, except that I find myself at a confluence of resonances between this paper, the biographical context that occasioned it, and a pandemic. Death has, understandably, been on my mind a lot lately, and when it came time to edit this paper-which didn't start out about mourning but ended up there-I realized what, or rather who, was missing. I needed, in my own queer way, to perform rituals of memory that collapse the distance between me and my grandmother, and writing has always been one such ritual for me. Theatre, as discussed in the remaining pages, is another. My grandfather had initially arranged for a special mass at his church in my grandmother's honour for this weekend, but because of COVID-19, it had to be postponed. The standard rituals of mourning in heterosexual time such as church 
services and graveyard visits were disrupted, so I've invoked her here, in a queer time of theatre criticism.

Because time is not linear, some stories cannot be told all at once or in order; the events they (fore?)tell have not yet happened, and more importantly the storyteller is not yet the person they need to be to tell that portion. I didn't start keeping an actual diary again until I began self-isolating due to the pandemic. I didn't know how to frame and introduce this piece of writing until I read José Muñoz's Disidentifications (1999) as part of another project. I didn't yet have occasion to align my personal mourning implied by the diary form with the collective queer mourning I experience in the theatre. I didn't know what I was trying to say until this was no longer an unedited diary, me talking to myself.

In a diary, there is (usually) no goal, no point to make, no through line around which it revolves, no clear distinction between relevant and tangential, noteworthy and mundane. Academic papers (usually) are not designed to accommodate such a hypercontextual, meandering approach to a subject. On the topic of fieldwork notes and diaries for anthropologists, Michael Taussig points out how diary, as a form of storytelling, is temporally unstable upon rereading "precisely because its order is as remorseless as the rising and setting of the sun," and this in turn disrupts and blurs the colonial gaze of the institution $(2011,50)$. One anonymous peer reviewer described this present project as "writing in the margins of straight performance scholarship," an image that I think beautifully captures the tense negotiation between theory and experience here, as does the temporal distortion of incorporating reviewer notes in the text. After all this isn't strictly a diary, but an invocation of diary. While the form calls attention to the reality that no knowledge emerges fully formed all at once and in order, it also obscures the revision and curation enabling it to function in this setting, an obscuring I plan to resist by emphasizing sutures and incisions.

In teasing out the connections between disidentification (a survival strategy marginalized people adopt of repurposing and revaluing texts that Other them), and melancholia (variously described as chronic depression or excessive mourning), Muñoz resists an individualizing Freudian model of melancholia as a failure to "get over" the trauma one mourns, and instead focuses on collective melancholia as a positive tool of remembrance. For him, melancholia "is a mechanism that helps us (re)construct identity and take our dead with us to the various battles we must wage in their names-and in our names" (1999, 74). Performances of disidentification allow for a queer presence in excess of the bounds of the texts or scenarios being recycled. The metaphysical implications of that excess presence are what concern me in the remaining pages.

The performances I wish to call forth involve queer and queer-coded characters that cross boundaries between worlds, and through this crossing glimpse Muñoz's queer 
futurity. For Muñoz, “queerness's form is utopian. Ultimately, we must insist on a queer futurity because the present is so poisonous and insolvent" $(2009,30)$. However, the impossibility of reaching that future creates the "melancholy and ambivalence" of disidentification $(1999,58)$. In order to consider the stakes of this vision for these queercoded characters, I take Susan Greenwood's work on magical consciousness to heart:

The imagination is not just the preserve of children, or those who refuse to grow up; it is a mytho-poetic terrain most obviously, but not exclusively, utilized by artists, poets, and musicians. Magical thinking is creative thinking that goes beyond the immediately apparent. If a wider perspective is taken, it is possible to investigate what lies beyond the horizon of the here and now by venturing into the imaginal mind. $(2013,199)$

As this explicitly isn't a research article but a personal response to a set of texts ${ }^{1} \mathrm{I}$ believe magical consciousness is an appropriate mode of inquiry; even if it weren't, then we could say I'm playfully answering Jacques Derrida's call "to speak to the specter, to speak with it, therefore especially to make or to let a spirit speak" (2010,11, emphasis in original). Derrida's notion of hauntology-the complex ontology of ghosts-comes from his meditation on communism, Spectres of Marx; Marx, like the embalmed body of Lenin continually on display, continues to haunt present-day capitalism through his perpetual return to the conversation $(10){ }^{2}$ Just as these communist spectres continually portend the death of capitalism, the queer spectres of the theatre reappear to disrupt heterosexual spacetime. To return to Greenwood "if we entertain the proposition that during an experience of magical consciousness spirits share a degree of corporeal materiality and possess mind, then the minds of entities-in whatever form-and ours can meet in a wider consciousness" $(2013,207)$. However, communing with spirits is notoriously indirect. I therefore ask the reader's indulgence as my writing style wanders between critical theory and personal mourning.

This particular entry was written over two days, not one. ||cut || I have dismembered my initial entries (by printing them and literally cutting them up, indicated by caesurae surrounding the word "cut" ||cuT | and rearranged the

\footnotetext{
${ }^{1}$ This article started its life as an exam journal/paper responding to a list of 12 critical performance studies texts but has since morphed into a response to a number of performance 'texts'.

${ }^{2}$ Vladimir Lenin (1870-1924), first leader of the Soviet Union, was famously embalmed and put on display in Red Square in Moscow instead of buried. His mausoleum remains open to visitors to this day. The complicated process of preserving the body forms the subject of Vern Thiessen's play Lenin's Embalmers. I am indebted to an anonymous peer reviewer for pointing out this connection between the communist themes of Spectres of Marx and my reading of Lenin's Embalmers (see entry " 15 October 2018”).
} 
fragments of the diary into a more digestible/consumable product-all the better to be in-corp-orated-a stage of contact between my body and yours, a performatic crossing of the veil simultaneously distorting and transmitting affect. ${ }^{3}||_{\text {cuT }}||$ In general, one does not go back and edit a diary unless the omission is just as important as what's included. Actually, perhaps that is also true in this case: what I've excised and replaced with ellipses $\{\ldots\}$ or paraphrased in curly braces \{\} is more important off the page in the realm of queer biography, the banal part of the story that theatre's ghosts and mine don't need to tell onstage/on-page because this diary isn't our body yet anymore. ${ }^{4}$

\section{OCTOBER 2018}

Who are we "other fairies"? As Shakespeare wrote in A Midsummer Night's Dream:

[...] we fairies, that do run

by the triple Hecate's team

from the presence of the sun,

following darkness like a dream,

now are frolic. [...] (V.i.373-77)

In the final moments of the play, the fairy Puck cleans up their literal and figurative mess in direct address to the audience, easing the transition back out of our shared reality. Unlike the other characters, including the rest of the fairies, Puck lingers in the final moment. While there have been many dramatic interpretations of that monologue illustrating various motivations and meanings, structurally I wonder why this task specifically falls to (or is taken up by) Puck, the queerest entity in the show. In this moment he becomes distinguished from the rest of the fairies by talking to the other beings-he becomes the Other(ed)('s) fairy.

In his Introduction to The History of Sexuality, Michel Foucault (1990) has a chapter titled (in English translation) "We 'Other Victorians'," a reference to Steven Marcus's The Other Victorians. For Marcus, the "other Victorians" were members of a "sexual subculture" abjected by mainstream Victorian society and yet still possessing an "otherness [...] of a specific Victorian kind" (1966, xiii-xiv). Foucault transforms this phrase into "nous autres, victoriens" (lit. "we others, Victorians") which further emphasizes how this otherness is a part of Victorian subjecthood instead of separated out from it $(1990,4)$. The discourses of sexuality circulating in the Victorian era create these others,

\footnotetext{
${ }^{3}$ This cut-and-paste, collage aesthetic is common in trans autobiography (Bornstein 3).

${ }^{4}$ The politics of omission in diaries is patently queer, as "our" diaries are often censored both in their writing and in their later publication
} 
who in turn performatively assume this otherness as a supposedly subversive tactic that is in fact an integral part of those discourses. And yet, through his use of "we" Foucault still counts himself among these "other Victorians"; even as he critiques this positionality, he is writing from within it. I use "we other fairies" in a similarly disidentificatory manner. While ultimately this marginalized position in relationship to other worlds is integral to their propagation, I nevertheless find it vital to undertake (puns intended) the project of locating and frolicking among the other fairies. After all, the ghosts of our (straight cis) ancestors get funerals, genealogies, canons. Our queer ancestors get theatre. ${ }^{5}$

Who are our queer ancestors? I believe that they are those banished from the churchyard or the cemetery, from the record books and the family trees, condemned to return only onstage. They are the cyclical re-performance of the Turnerian breach, the traumatic memory, they are the ghosts who suffered the damnatio memoriae of a love that could not speak its name and thus was never archived. ${ }^{6}$ They are "fairies" in that other sense. They must belong to other families, imagined ones, mythical ones, not ours. Their traffic is the stage, not the cemetery. Queerness is simultaneously banished from and contained within the stage/screen. But their very inadmittance requires an explosion of discourse. Even as we other fairies are expelled from the dead city gates, we are not so easily forgotten.

(Perhaps the more basic question is, who are "we"? Such universalizing statements are painfully essentialist, and I hold no illusions of a unified audience with a standard monolithic interpretation or experience of the text. Moreover, it universalizes the abjection of queer ancestors [and the memorialization of cis straight ancestors, for that matter], which is very much a product of Western imperialism, cisheteropatriarchy, and white supremacy. Partially this is a limitation of English, which does not distinguish first-person plural inclusive and exclusive ["we" as in "you and I" vs. "we" as in "us and not you"]. For me, "we" in this instance is a linguistically-exclusive marker of solidarity with the other "other fairies", but who precisely is included in this "we" is purposefully vague to allow for varying levels of hailing and resonance with this framework. It's also imperative to point out that while "we other fairies" is explicitly inclusive of queerness,

\footnotetext{
${ }^{5}$ Here I jump off from Joseph Roach's description of cities of the dead: "Cities of the dead are primarily for the living. They exist not only as artifacts, such as cemeteries and commemorative landmarks, but also as behaviors. [...] Memories torture themselves into forgetting by disguising their collaborative interdependence [which] may be carried out by a variety of performance events [...]. To perform in this sense means to bring forth, to make manifest, and to transmit. To perform also means, though often more secretly, to reinvent" (1996, xi).

${ }^{6}$ Victor Turner's notion of 'social drama' describes the structure of ritual as "breach, crisis, redress, and either reintegration or recognition of schism” (1982, 69, emphasis in original). The continual breach of social norms by our queer ghosts perpetually triggers crises that must be resolved, usually not in our favour.
} 
queerness is not the only or even necessarily the organizing marker of otherness in this framework; as with Marcus's other Victorians, it is a hodgepodge of rejected ontologies.)

To be clear, these rituals of mourning are not mutually exclusive: there are plenty of entities with both gravestones and plays about them. But funerals, plays, holidays, etc., each perform memory and trauma differently. My (presumably) straight grandmother's memory is reanimated variously as a family member to be sent off on her next big journey (funeral), a source of knowledge and history (family storytelling), a physical presence to negotiate (grave), a traumatic separation to be commemorated (the rescheduled mass), and now a touchstone and guide for lost writers and readers alike in this paper/diary/performance. She is dead and I am alive (or "not yet dead", depending on how you look at it), but we are both other fairies in this moment, because we are invested in the portal of this paper stage remaining open as long as possible, so that we may stay connected a while longer.

\section{OCTOBER 2018}

\{... I attend Alex Donovan's 2018 production of Vern Thiessen's play Lenin's Embalmers at the University of Alberta.\}

One of the central themes of Lenin's Embalmers is death and the complete lack of control one has over what those who survive you do with your remains $\mid$ |cur | | (incidentally a major concern for queer and trans people). | |cuT || Lenin's (played by Thiessen in this production) last line is, "I could die today. If only... If only they'd stop waiting," after which he exits through the house right door (Thiessen 2010, 118). As the curtain falls on this production the cast comes to do their bows, but Thiessen is conspicuously absent. It is only as I proceed to the lobby that I see Lenin on display, guarded by Apparat 1. As that final piece clicks into place, the missing counterexample for a halfbaked thought that's been floating around in my brain for a year or so now, I know for sure that there is a paper here I need to write.

The stage directions for this moment are implied to be optional: "as the audience leave, perhaps they too pass by Lenin. Taking the story with them" (ibid). Donovan's placement of the casket in the lobby forces the audience to deal with their complicity in keeping the memory of Lenin alive. Unlike the other characters who return to the ether with the curtain call, Lenin is not allowed to die; even as his "dead" body is on display, his ghost is still animated in the theatre-suspended animation? The ritual is not complete, so he cannot pass on until the audience has dissipated. Lenin is trapped in the eternal present. 
Donovan's description of this conundrum is illuminating:

Lenin begins and ends the play from beyond the grave. He haunts the space and is the only unwavering presence in the show. [...] According to Jewish folklore, the soul becomes trapped on earth after death if they do not bury the body. From dust to dust. Lenin's embalming has prevented his soul from moving on and so he is stuck on earth as a wandering soul. There is no evidence in the text he can stop or alter the events that take place. Bound by the scripted action of the past he can do nothing but watch. Without a corporeal body, Lenin cannot alter events. He can only present the events of the past by putting on a play with whoever is available to do so. [...] Lenin is the only actor who remains in character from the beginning to the end, he is never a part of the ensemble. (2018b)

I don't think it's a coincidence that Lenin, who feels trapped by the immortality of the stage, is straight (as far as we know). So often the spirits I will consider in this vein are desperate to live, to spend as many seconds on the stage as possible before being whisked back into impossibility. It is again no accident that most of those spirits are queer. While certainly a topic of controversy, it is not farfetched to claim that characters inhabit/possess an actor's body for the duration of a piece then leave at its close (Schechner 2003, 197-202). It is also fairly standard to consider the queer chaos of the stage in the context of Mikhail Bakhtin's carnivalesque: the social order is flipped topsyturvy only to be reinscribed by the end of the carnival's allotted time $(2004,686)$. The stage presents/makes present these spirits and grants them limited reign over the performers for various and sundry cultural reasons before the performance ends and our mundane lives move on. What has received less attention are the stakes of this practice for the spirits themselves. The stakes for the ghost of Lenin are very high as he faces an explicitly unwanted immortality. The stakes for queer spirits are also high, because performance is one of the few times they are allowed on our plane.

I started thinking about these stakes because of the 2008 film Were the World Mine (WTWM, dir. Tom Gustafson). In this adaptation of A Midsummer Night's Dream, Timothy (Tanner Cohen) is cast as Puck in his boarding school's production of the play, and while trying to get his classmate Jonathon (Nathaniel David Becker) to fall in love with him, he ends up finding a recipe for the love potion and turning the town gay with that self-same love-juice. Timothy uses this as an opportunity to make the town understand just how miserable they've made him through their homophobia, but he soon realizes that he has caused more problems than he has solved, and that Jonathon's pansy-induced affections are not as satisfying as he had hoped. During the performance of the play, he must ensure that "all things shall be peace" by reversing the spell, which 
condemns him once again to be the only gay kid in town (or so he thinks). The way I remember him delivering\} Puck's closing monologue is both moving and illuminating:

If we shadows have offended

Think but this, and all is mended-

That you have but slumber'd here

While these visions did appear [...] (Shakespeare [1595/6] 1977 V.i.413-16; Gustafson 2008, emphasis mine)

\{I re-watch WTWM to verify the emphases in the above block quote and end up with a wrinkle in my argument.) Upon re-watching the movie, it turns out I was wrong about him placing emphasis on "you", but I find that misremembrance productive. "That you have but slumber'd here," whereas I live here. Here Puck is given free rein to determine the couples, and he uses it to create a queertopia where he is not alone. At the end, the town, having gone through the queer chaos of the carnival (literal and figurative), awakens back to their straight reality. Timothy does not get to wake up straight or remain in a queertopia, and Puck must return to the incorporeal, the reality of the stage fading as it always does. | | cuT | |

Finally, the spirits themselves remind me that for them this topic \{queer spirits onstage is literally life and death, as any discussion about ontology ultimately is (Derrida 2010, 9). I hear their call as I read Gilad Padva's comparison of WTWM and Zero Patience (1993, dir. John Greyson), a Canadian film musical about Gaëtan Dugas, the alleged patient zero of the HIV/AIDS crisis (Padva 2014, 145-68). The spirits remind me of the lyrics to the only number from the movie I know well, "Just Like Scheherazade": "tell the story of my life/ from zero hour to $12 \mathrm{am} /$ from the good to the bad/ tell the tale, save my life/ the life I could have had" (Greyson 1993). Greyson frames this song as Dugas's metatextual plea to the filmmaker to "clear my name" from the false accusation that he had started the crisis. Then again, the plot of Zero Patience revolves around precisely the same desire for disappearance that Lenin has, and for similar reasons of forced immortality. Since the lives (or lack thereof) of these spirits are in my young, untested hands, I ask myself: what might my responsibility and relationship to these beings be? | |cuT|| We perform stories for many reasons-entertainment, education, argument, catharsis, etc.-and enlist these spirits to help us tell these stories. We (mortals) know what we (the audience and performers) get out of it, but why do we (other fairies) come back? Do we have to? Do we want to? Do we need to?

\section{FEBRUARY 2019}


While many Shakespeare comedies have a similar structure to that of Midsummer, the fairy forest as a location seems to be especially conducive to queer world-bending. In WTWM, a large tree set-piece takes literal center-stage and prominently figures in many of the dream sequences. It operates as the source and locus of magic even before Timothy becomes Puck, even before its physical construction on the gymnatorium stage. Similarly, in regard to the forest in Benjamin Britten's 1960 operatic setting of Midsummer, Philip Brett has argued: “as the curtain rises on Britten's opera, we cannot fail to notice a crucial difference from the play. Even without the scenery we know that we are already, in more senses than one, in the woods. [...] In Britten's scheme it is the court of Duke Theseus that seems unreal and limiting, the final entry of the fairies marking a return to normal" $(1995,268-69)$. Instead of firmly policing the boundaries of reality between town and forest, Britten "has moved here [...] into a completely private world, a world of possibilities rather than of limitations" (ibid). The transmersion ${ }^{7}$ of realities in the forest both analogizes and enlivens the collapse and proliferation of identities. Performance transmerses its participants (actor, spectator, and medium) into a different plane of reality. In a theatrical performance, as the utopic (or dystopic) space of the transformed performance materializes, presences that belong to that space appear (present themselves) on this plane. Here I embrace the paradox of Derrida's hauntology: the ontology of performing ghosts relies on the infinitely receding present even as they inevitably return to restage their memory. For Derrida, hauntology is "larger and more powerful than an ontology or a thinking of Being [...]" $(2010,10)$. A specter both is and is not. Is it a particle or a wave? Yes.

In plays where the fourth wall is firmly enforced there is little occasion for interrogating the nature of these presences; regardless of whether or not the actor is really the character in any meaningful way, there is an ostensibly solid division between the conjured reality onstage and the reality inhabited by the audience. ${ }^{8}\{\ldots\}$ The performances I call forth here involve queer and queer-coded characters that cross boundaries between worlds and through this crossing glimpse Muñoz's utopic queer futurity $\{$ sic déjà vu\}. I am particularly partial to Andrew Buzny's interpretation of Timothy and Ms. Tebbit (Wendy Robie) in WTWM: "I do not contend that the 'dream'

\footnotetext{
${ }^{7}$ For the purposes of this paper I consider transmersion to be the result of Fischer-Lichte's (2008) transformative reenchantment. Instead of talking about unidirectional and individualizing 'immersion', 'transmersion' implies both a colliding of worlds and a collective coming together between the beings of these disparate realities.

${ }^{8}$ I will focus on the theatre vein of performance, recognizing that even here ontologically stable notions of 'character' and 'world of the play' are increasingly suspect (and with good reason). I also recognize it is unlikely a performer's consciousness is ever completely surrendered to a character or a possessing presence (Schechner 2003). On the contrary, the ability of an actor to consciously inhabit multiple worlds simultaneously as multiple (id)entities is precisely what spurs my inquiries.
} 
sequences are dreams, but moments of temporal disorientation that Timothy or Ms. Tebbit conjure when he or she steps out of the realist frame of the film" (2010, 26-27). Ms. Tebbit, being the English/Drama instructor who gives Timothy the magic script, takes Puck's structural role as liminal figure while Puck-as-Timothy moves into the liminoid position of being the subject of the movie; it is Ms. Tebbit who addresses the audience at the end, holding the flower and saying "who's next?" ${ }^{9}$ It also should be pointed out that she too is queer-coded; at one point a student calls her a dyke. ${ }^{10}$ When I was discussing this project with $\{\ldots\}$, she pointed out that in terms of production history, Puck has a long, rich tradition of queer presentation. Additionally, unlike fairies such as Titania and Oberon, he is almost never doubled (Puck's actor doesn't also play other roles), again marking him as an other fairy. The queerness of WTWM's version of the play therefore is not just an artifact of adaptation, but also relies on the queer renown of the character to facilitate the collapse between Puck and Timothy. Moreover, the increased spillage between the world of the play and the world of the movie affords Puck as a presence a greater ability to escape the bounds of his own world and envision other utopic presents, what Muñoz calls "queer world-making" $(2009,37)$. And yet, the inability to inhabit fully and permanently the border space between these worlds restages queer trauma. | |cuT|| Puck is constantly oscillating between liminal and liminoid spaces, blurring the thresholds that divide them from the mundane; indeed, lingering in the doorway and dancing queerly upon it. And the impossibility of remaining in the portal, which closes at the end of the show, is the perpetually restaged fort-da that drives the theatre (Phelan 1993). | | cut | |

Clearly, not every character onstage is (or even should be claimed as) queer. I'm actually making two separate points: first, ${ }^{11}$ that the process of theatrical possession is itself inherently queer (in an expanded sense of the term), and second, that the queer (in a focused sense of the term) spirits have an extra investment in this process because

\footnotetext{
${ }^{9}$ The liminal is the stage in a ritual when the typical rules of social reality are suspended while the celebrants undergo some change, and when the transformation is complete there is a return to order (Schechner 2003, 188-89). The liminoid occupies a similar cultural position but instead of present-ing that change, it is represented (Schechner 2003, 159-60). To use Midsummer, the staging of Pyramus and Thisby is a diegetic liminoid space. Diegetically the forest is liminal space, where the lovers enter, are transfigured, and return to Athens to be married. The play itself is extra-textually a liminoid space. That said, liminal and liminoid cannot so easily be separated; first of all, such as Schechner's articulations of the liminoid tend to ascribe it cultural superiority over the liminal (conveniently liminoid structures are more common in the West). Secondly, both liminal and liminoid performances take place in the 'liminal' transmersed plane between realms (the second 'liminal' channeling the term's popular usage as referring to enchanted spaces where 'the veil between worlds is thinner').

${ }^{10}$ Even more interesting for my purposes, Ms. Tebbit, consistently refers to herself and Timothy as "we", even when talking about his unilateral actions, e.g. "have we had our fun yet?"

${ }^{11}$ See entry "13 February 2019" below.
} 
of their limited access to extra-theatrical invocation, remembrance, etc. Or perhaps I only mean the ones who know they're in a play. Puck addresses the audience, knowing they're there, and is consequently implied to be familiar with their world and its difference from his. He can recognize his lot onstage, and a world lived differently, and mourn the distance. The theatre is once again the stage mirror/mirror stage. | | cut $\mid$ |The mimetic project in theatre is often described as the stage holding a mirror to reality, though this notion is one of the main sticking points in conversations about mimesis because the stage creates the very reality it purports to describe while erasing other crucial aspects of reality (Case 1988). In Lacanian psychoanalysis, the mirror stage of development is the point at which a child (or animal or other entity) recognizes themselves in a mirror. Puck and we other fairies recognize ourselves in the mirror the stage holds up between realities, but we also recognize the distortion of that image, leading to a disidentificatory ambivalence where survival requires us to reach through the mirror into that other looking-glass reality then break the mirror to prevent the distortions from remaining or seeping through. | | cur || Hence Lenin, forever trapped in the performatic present; hence the eponymous Three Mysterious Women, with only the repertoire to tell their stories through constraining archives of text; hence the boys in Shakespeare's REJ and Timothy in WTWM, who must "give up the ghost" and return to their heterosexual milieu. ${ }^{12} \mid$ |cut $\mid$ |

Nana died three months before I came out as trans, but I like to think it wouldn't have mattered to her. My mom's family lives in Ohio, and most summers we would drive the eight hours to my grandparents' house to visit. Perhaps it was the presence of my lesbian aunts, the carnivalesque reversal of power (my dad was no longer the final authority), or the firm acceptance from Nana and Papa-likely all three-but I loved going out there because it gave me space to be queerer than I was able to be back home. At the risk of confirming a stereotype, they knew way before I did, so they took it in stride when I eventually came out. But, inevitably, the summer would end, and we'd have to go back home. For my parents and brother, this drive home was the end of a vacation; for me, it was the end of my freedom to exist as a fuller self. The feeling I got whenever we packed up the car to return to Pennsylvania is the same feeling I get whenever I watch WTWM, or Midsummer, or Zanna, Don't!, or Night at the Museum. It's not that the proverbial grass was greener on the other side of the state border: it's that the grass grew there at all.

\section{FEBRUARY 2019}

\footnotetext{
${ }^{12}$ See entry "10 February 2019" below for discussion of these texts.
} 
For a long time in Western societies, the explicit presentation of content we might today call LGBTQPIA was effectively-if not expressly-banned, to say nothing of personal queerness. In the United States, for example, the Motion Picture Production Code (1930-1968), Code of Practices for Television Broadcasters (1952-1983), and Comics Code Authority (1954-2011) all prohibited depiction of "sex perversion" at one point or another. Sodomy, meanwhile, wasn't uniformly legal there until the Supreme Court's 2003 decision in Lawrence v. Texas. As such, queer characters, plots, settings, histories, and experiences were (and still are) often relegated to subtext or communicated through queer coding. As these restrictions have relaxed and queer voices have taken more prominent places in media, the trauma embedded in this subtextualization has become a theme to explore. WTWM restages the queer rage at the heart of Puck. Britten's Midsummer eschews the mundane world and relishes in the fairy world. Repression has not eliminated queerness but occasioned its proliferation as an unresistingly resistant discourse. || cut ||

I have referenced shows which I have not yet described, so let me unpack them for deeper examination in this light.\{...\} On stage, queer world-crossings are not just narrative threshold crossings but transmersions instantiated in real time with the audience. In Shakespeare's REJJ, playwright Joe Calarco (1999) adapts another Shakespeare play, Romeo and Juliet, and sets it in an all-boys school (as with WTWM). Four boys create a secret club where they can read and re-enact the banned play (no reason is given for its banishment), and as their "play" progresses the burgeoning queer romance between the boys playing the titular star-crossed lovers threatens to destroy them all. Nearly all of this must be read between the lines and through staging because the script is almost excruciatingly faithful to Shakespeare's original text. As an adaptation instead of a retelling, it makes sense that such fidelity is an important strategy in making strange/making queer the original text (which historically would have been performed by all men anyway). This makes it all the more perplexing that some of the lines are from a different play. Midsummer appears again in REJ at key moments, with some of the same lines that were emphasized in WTWM. For instance, before we even hear any lines from Romeo and Juliet, we hear the "we fairies" passage. Once again, the queer legacy of Midsummer is invoked to provide a similar queer legitimacy for this ludic space. In the script notes, Calarco is very clear that this show isn't just about homoeroticism but about ritual: "the evening should feel like a communal event. For this reason, the actors never leave the stage except during intermission. The more you can create the effect that this group of students is a community, or tribe, the more heartbreaking it will be at the end when they realize their 'dream' must end" $(1999,8)$. This is a pun, because the next time Midsummer appears is with the return to reality, as Student 1 repeats the "we fairies" passage in an attempt to hold onto the fading dream before Student 2 counters with "if we shadows have offended..." Here, as in WTWM, 
these lines serve as ritual signposts for the queer chaos animating the lovers of the respective stories and as a shorthand indicating specifically queer iterations of the Shakespeare plays.

I saw a production (Kill Your Television 2018) of Shakespeare's REJ at the University of Alberta with $\{\ldots\}$ and we had very different reactions to the mise en scène. For her, the production lacked sufficient communication of the stakes due to all the authority figures being offstage and the script providing no additional context. This made it hard for her to buy into the world of the play. In contrast, I bought it wholeheartedly for two major, related reasons. I was raised in a fundamentalist Christian home, so the placement of the story in a Christian school and my knowledge of queer media allowed for a sort of shorthand by which I could call up my own memories to fill in the stakes of the play's world. This call to memory was primed by the pre-show soundtrack, which played Christian tunes on an organ. Perhaps my personal ghosts gave me different access to the ghosts summoned by the production; perhaps they were in fact the ghosts being summoned. \{My friend's coterie of associated ghosts had no urgent need for participating in this production-mine did.\}

Three Mysterious Women (Peter Eliot Weiss) also reworlds Shakespeare, disrupting the hegemony of the text by (sometimes literally) cutting up the scripts of Hamlet and King Lear and stitching them together in novel ways from the perspective of three of the dead female characters. \{...\} Ophelia finds herself alone and mad in a strange, nondescript place. Soon, Gertrude appears in this void and they interact. Meanwhile, Cordelia is also in this barren land, and the three women figure out how to navigate their current situation, now that they've all died and are somehow stuck with each other. As they learn more about each other, an intimacy develops between them with varying degrees of homoerotic energy. Eventually, they come to realize that their original plays delimit the expression of their now-metatheatrical existence, a fact that frustrates and saddens them, but causes them to decide that they will use the gaps between the text and the body, between what is said and what isn't said, to speak truth to their new understanding. As the play comes to an end, they shred the texts.

This final resolution dramatizes the dynamic at the heart of Diana Taylor's The Archive and the Repertoire:

"Archival" memory exists as documents, maps, literary texts, letters, archaeological remains, bones, videos, films, CDs, all those items supposedly resistant to change. [...] There are several myths attending the archive. One is that it is unmediated, that objects located there might mean something outside the framing of the archival impetus itself. What makes an object archival is the process whereby it is selected, classified, and presented for analysis. [...] The repertoire, on the other hand, enacts embodied memory: performances, 
gestures, orality, movement, dance, singing-in short, all those acts usually thought of as ephemeral, nonreproducible knowledge. [...] Embodied memory, because it is live, exceeds the archive's ability to capture it. But that does not mean that performance-as ritualized, formalized, or reiterative behaviordisappears. $(2003,19-20)$

The archive-i.e. Shakespeare's texts-limits the possibilities of expression for the three women, especially in a culture that privileges its rigidity so predominantly (22). It is in the repertoire, the actual performance and extratextual ephemera of their staging, that these women can resist its sway. Importantly, Taylor warns that "performance belongs to the strong as well as the weak" and that her notion of archive and repertoire "too readily falls into a binary, with the written and archival constituting hegemonic power and the repertoire providing the anti-hegemonic challenge" (ibid). However, in this case, by colliding and dismembering archives, the repertoire allows for the frolicking of these three spirits. This is of course reliant on Weiss's text which is its own form of archive, and since a man is writing this text there is the potential for a reinscription of the patriarchal power it critiques, but here the archive and repertoire "work in tandem," "both exceeding the limitations of the other" (Taylor 21).

Despite what my sampling implies, the queer transmersion of worlds does not necessarily only pertain to Shakespeare and his theatrical descendants. Zanna, Don't!: A Musical Fairy Tale (Tim Acito and Alexander Dinelaris) provides an interesting iteration of these points. Zanna has cupid-like powers in a world where the majority of the population is homosexual and it is heterosexuals that are discriminated against. When his friends Kate and Steve come out as straight, he vows to send them to a world where they can be themselves. This comes at the cost of his magic, and he ends up creating a world where heterosexuals are the norm and homosexuality is suppressed. He thus takes on the outcast role in Kate and Steve's place because, in the move between worlds, he retains his queerness (and memory, unlike everyone else). Zanna, as with WTWM's Timothy, is then surprised to discover that he is not the only one to cross the hero's threshold into a heterosexual reality, but that the narrator, Tank-until this point a background character-also remembers the previous world, and they fall in love. ${ }^{13}$ Zanna and Timothy are both masters of two worlds who had to leave their world of bliss for the sake of the larger society. It is noteworthy then that the marker of their mastery is their memory of the previous world, a memory that is also retained by their love interests. ${ }^{14}$ That both Tank and Jonathon also remember their respective queer worlds,

${ }^{13}$ Here I reference Joseph Campbell's monomyth, recognizing that its claims to universality are specious at best. However, in the case of these two shows, the hero's journey fits well.

${ }^{14}$ Buzny notes that in the case of WTWM this is partially due to Jonathon also being a queer destabilizing figure even before the spell, due to his shared ability with Timothy to step outside of the 
or at the very least the feelings aroused there, preserves the queer hope that these works embody and rewards the heroes for their reluctant abandonment of queertopic realities. It is also implied that they are the heroes' boon; in exchange for curbing the chaos of a queer reality, the fairies may keep their men. Zanna and Timothy's heroic journeys restage the coming of age ritual that for them involves transfiguration of a liminal queer space into a safely heterosexual one, and the marker of their integration into the mundane straight world is their neoliberally-accepted union with a conventionallymasculine (by comparison) boy. | | cut | | They are no longer other fairies, they're simply "fairies"-Puck, meanwhile, is removed from the closing threshold he never gets to cross, assuming he even wanted to.

\section{FEBRUARY 2019}

\section{| |cuT $\mid$}

Consider the ontology of possession; there is something queer about another being taking up residency in your body. Deprived of their own bodies, these ghostly beings may only return to our plane in someone else's, and if there's anything cisheteropatriarchy can't stand, it's the sex which is not one. Acting has long been associated with sexual impropriety, from sex-work to promiscuity to queerness, partially because one must be not oneself, in all senses of the word (Nellhaus et al. 2016). This uncanny doubling creates a gap between the corporeal body and the body politic, between reality and imagination, between identity and performance (Kobialka 1999; Roach 1996). Whether or not these possessing spirits ever had literal bodies of their own or whether these creations we call fictional were indeed created by artists is another matter, though an interesting one. Given the inevitable citationality of performance, perhaps we end up summoning the same archaic ghosts without realizing it, just in fancier hats. Time is cyclical. In a contemporary Western understanding, humans are born, grow old(er), and die-a linear progression-whereas spirits on the stage are constantly "dead, live, re-dead, re-live" (Schneider 2011, 178). They must do it all again whenever they are summoned; sometimes the story has changed, and sometimes they have changed, but their fate is the same: to return to this plane and live here however briefly. | | cur | |

It is by no stretch of the imagination novel to claim that theatre at its core is about ritual, memory, and trauma. Marvin Carlson famously refers to theatre as a "memory machine": "[theatre] is the repository of cultural memory, but, like the memory

heterosexual time of the diegesis (2010); Tank is similarly implied throughout Zanna, Don't! to share Zanna's queer love magic. 
of each individual, it is also subject to continual adjustment and modification as the memory is recalled in new circumstances and contexts" $(2003,2)$. Performance of memory is frequently used as a repertoire of counter-memory "attend[ing] to [...] the disparities between history as it is discursively transmitted and memory as it is publicly enacted by the bodies that bear its consequences" (Roach 1996, 26). | | cuT | | Far too often, when trans people die, we are misgendered in obituaries, headstones, eulogies, genealogies, and other instruments of cishet mourning. Despite this, our queer bodies, our lived experiences, and our influence on other living beings are a vehement countermemory to these official histories, and telling these stories is a crucial act of witnessing (Cram 2012). | | cut | | Thus, the specific ghosts generated by the memory machine that I'm interested in contain a (dis)embodied repertoire of queer counter-memory that must traverse the temporal and spatial distance between our plane of existence and theirs. $\mid$ cut ||

But the nature of these presences is not my most pressing ontological concern; whoever these spirits are, however they got here, let us assume they occupy the stage. ${ }^{15}$ | $\left.\right|_{\text {cut }}||$ That said, in a performance we other fairies are not coterminous with characters, nor is there necessarily a one-to-one correlation between fairies and characterizations. Yet, since characters are what manifest on stage, that is the easiest way to interact with and conceptualize them. || cur || Nor is it my concern how spirits manifest logistically, though possession seems to imply a Cartesian soul/body split that I want to avoid. If I had to tangentially hazard a guess, I'd opine that with each instantiation of a performance (including rehearsal), the body-soul of the performer intra-acts with the (id)entity in such a way that it emerges as part of them only to become separate through the termination of the performance (Barad 2006). Nor am I able to comment on how the realities beyond our current mundane one are structured outside of their contiguity with ours. ${ }^{16}$ My concern is these contiguous points between realities and their perception by their respective inhabitants. In other words, I can only talk about these places and beings by talking about the points of contact between these other worlds and ours, the moments of our intra-action.

\footnotetext{
${ }^{15}$ I am not oblivious to the fact that from an empirical standpoint this is unfalsifiable speculation at best. To that I say, not only am I not a scientist, but I use this argument to turn the traditional conversation about the ontology of the actor on its head. From a mortal perspective, the actor takes on a character, is transmersed into the world of the play, and returns relatively unchanged to the mundane. From an astral perspective, how might this process work?

${ }^{16}$ Does this reality cease to exist when we' re not observing it, a proverbial tree falling in a forest? Or do these places and characters have offstage lives and politics etc.? Are all performances happening simultaneously for these spirits? Are they fractured reflections of one nebulous spirit world or infinite discrete worlds? Are we spirits to them?
} 
INTONATIONS

It is only in the comparison of realities that one can determine which reality is which, although which reality is "really" real reveals itself to be a matter of perspective. In the Ya Dead, Ya Dead arc of the Achievement Hunter series Let's Play Minecraft, the players enact alternative versions of themselves, such as a world where Gavin ${ }^{17}$ (Gavin Free) and Michael (Michael Jones) were previously married. When another player semiaccidentally shoots Gavin, they discuss the ethics involved, and Michael says: "If I go, if I right now say 'I bet you can't shoot me,' and you shoot me, in real life? It's still your fault, just so you know." When it is pointed out that they're simply playing a game, Michael responds: "He's dead and he's not coming back! It's pretty real to me!" (Achievement Hunter 2018, 16:59-17:13). Regardless of whether or not Gavin/Free is dead in our reality, the fact remains that in the game/series, Gavin is dead. Whether or not our reality is real is frankly irrelevant because in the moment we experience it as real.

There is a theory, the simulation hypothesis, in which the universe is just a simulation run by beings beyond our reality, in the same way that in video games we maneuver beings. ${ }^{18}$ I don't know if that's true, but I do believe, for however brief a moment, however framed and rehearsed, what happens on the stage is real for the ghosts who are summoned upon it. If I don't know I'm in a simulation, then the ontology of the person(s) controlling me, who by definition does not exist on this plane except through their manipulations, has no bearing on the fact that the laws of this reality, such as they are, apply to me in this moment in time and space. The rules may be different depending on the reality, and I may not know all the rules, but they still apply. It doesn't matter if I'm dreaming, because the answer is not going to stop a person chasing me in my dream from chasing me. It doesn't matter if it's "just a game", because diegetically Michael cannot interact with Gavin as a living being.

Johann Huizinga gets at this in his analysis of play:

The consciousness of play being "only a pretend" does not by any means prevent it from proceeding with the utmost seriousness, with an absorption, a devotion that passes into rapture and, temporarily at least, completely abolishes that troublesome "only" feeling. Any game can at any time completely run away with the players. The contrast between play and seriousness is always fluid. $(2002,8)$

${ }^{17}$ Here I use first names to refer to the in-game persona and last names to refer to the performer.

${ }^{18}$ E.g. Chalmers 2005. Descartes returns unbidden to the discussion; basically, this is a reformulation of the question of how one knows whether or not we are in a dream. $\{. .$. 
Even if we have knowledge that the transmersed reality is different from our mundane reality, that we operate in both simultaneously, ${ }^{19}$ and that we will almost certainly return to the mundane reality-from our perspective the so-called real reality- whether our invocation of other realities is playful or serious, we must still navigate them according to the laws of each reality as it manifests to us. ${ }^{20}$

So, it doesn't matter if Lenin is "really" in the casket, because at that intersection between his world and our world, he is trapped-temporarily perhaps, but still trapped. Thiessen still has to lay in the casket because Lenin has still not bowed out. Meanwhile, for two glorious hours, Puck and Zanna can make anyone fall in love; Romeo and Juliet can be two boys kissing; Cordelia, Gertrude, and Ophelia can write their own damn story-for a brief, shining moment, the transmersed worlds are queer. In WTWM Timothy says "I don't want to go back to real life," to which Jonathon responds: "this is real" (Gustafson 2008). They are talking about different registers of reality, but both end up being correct when it is revealed that even after the return to normalcy Jonathon still wants to be with him. | | cur || Transmersion is simultaneously a cause for queer hope and queer mourning, precisely because it is a bridge between ultimately incompatible realities. However, the faint possibility of fully crossing over into the queer world, of the portal closing with us on the other side, animates and emboldens our desire for a world lived differently. Admittedly, such a complete crossing would constitute madness, a denizen of a reality no longer shared by anyone else or material fact, but to be fair, some of us were mad to begin with, and we still have to navigate our realities simultaneously. | l cut $\mid$

Even as this vision of other worlds is decidedly utopian, I want to avoid exoticizing these other worlds or using them to further an Orientalizing project. Britten's Midsummer, for example, relies on Orientalist tropes to exoticize his forest (Brett 1995). Similarly, I worry that such a queer reclaiming of the memory machine might become a form of homonationalism, an attempt to (re)claim a specifically queer time and place. $\{\ldots\}$ This discomfort also attends the fact that not all ghosts that haunt the stage are queer, or benevolent. While, like Padva (2014), I find WTWM more transgressive than regressive, I take to heart his warning about the conservative bent of nostalgia, even the queer nostalgia that animates musicals. I do not have answers to

\footnotetext{
${ }^{19}$ In performance theory, this concept of perceiving multiple realities simultaneously is variously referred to as "binocular vision", "not me...not not me", and being "haunted" (Carlson 2018, 50-51).

${ }^{20}$ Greenwood takes a similar approach to belief, concluding that "questions of belief or the reality or non-reality of spirits, while interesting in principle, can be a straitjacket for an alternative perception afforded by communication with non-material entities. The issue is one of a different perception afforded by magical consciousness" (2013, 204).
} 
these concerns, they remain beyond the veil blanketing this performance (of scholarship).

\section{SOME OTHER FUTURE DATE}

In conclusion, theatre is gay, but we knew this. Less glibly, theatre affords both queer audiences and queer spirits (as well as our cishet counterparts) the opportunity to communicate across the veil between worlds and to simultaneously restage, mourn, and overcome the trauma of death and lost memory. By creating space for this transmersion of realities, theatre provides opportunity for honouring of queer spirits and of ancestors of forgotten, refused, and fictive families. It also allows us to glimpse other worlds, sometimes better than our own, sometimes worse, sometimes altogether strange, but more often than not steeped in queer futurity.

We other fairies, simultaneously swept to the margins and summoned ad infinitum, are given space to haunt to our hearts' content, provided we "run [...] from the presence of the sun" at the end. I have sloughed off a piece of myself to embed in this diary, and this part of me contacts Nana every time someone performs an act of reading it. When you stop reading this paper, you go back to your life, and Nana and I go back to a world without each other. For now. But until then, we other fairies are frolic.

\section{BIBLIOGRAPHY}

Achievement Hunter. 2018. "Gavin Two." Ya Dead, Ya Dead, part 3. Let's Play Minecraft, episode 305. Rooster Teeth, 23 Mar. https://roosterteeth.com/watch/let-s-play-2018-minecraft-episode-305-gavintwo-ydyd-part-3

Acito, Tim and Alexander Dinelaris. 2003. Zanna, Don't!: A Musical Fairy Tale. Performed by Jai Rodriguez, Robb Sapp, Shelley Thomas, Jared Zeus, et al., John Houseman Theater, NYC.

Bakhtin, Mikhail. 2004. "Rabelais and His World." In Literary Theory: An Anthology, edited by Julie Rivkin and Michael Ryan, 686-692. Maiden, MA: Blackwell.

Barad, Karen. 2006. Meeting the Universe Halfway: Quantum Physics and the Entanglement of Matter and Meaning. Durham: Duke UP. doi:10.1215/9780822388128 
Bornstein, Kate. 1995. Gender Outlaw: On Men, Women, and the Rest of Us. New York: Vintage.

Brett, Philip. 1995. "Britten's Dream." In Musicology and Difference: Gender and Sexuality in Music Scholarship, edited by Ruth A. Solie, 259-280. Berkeley: U of California P.

Buzny, Andrew John. 2010. Queer Alchemy: Fabulousness in Gay Male Literature and Film. MA thesis, McMaster University.

Calarco, Joe, adapter. 1999. Shakespeare's REJ. New York: Dramatists Play Service.

Carlson, Marvin. 2003. The Haunted Stage: Theatre as Memory Machine. Ann Arbor, U of Michigan P.

-. 2018. Performance: A Critical Introduction. $3^{\text {rd }}$ ed. New York: Routledge.

Case, Sue-Ellen. 1988. Feminism and Theatre, New York: Methuen.

Chalmers, David J. 2005. "The Matrix as Metaphysics." In Philosophers Explore the Matrix, edited by Christopher Grau, []. London: Oxford UP. http://consc.net/papers/matrix.html

Cram, E. 2012. “'Angie Was Our Sister': Witnessing the Trans-Formation of Disgust in the Citizenry of Photography." Quarterly Journal of Speech 98 (4): 411-38.

Derrida, Jacques. 2010. Specters of Marx: The State of the Debt, the Work of Mourning, and the New International. Translated by Peggy Kamuf. New York: Routledge.

Donovan, Alexander, dir. 2018a Lenin's Embalmers. Written by Vern Thiessen, performed by Thiessen, Doug Mertz, Diego Stredel, et al., Studio Theatre, Timms Centre for the Arts, U of Alberta, Amiskwacîwâskahikan [Edmonton], Treaty 6/Métis Region 4, AB, 15 Oct.

-. 2018b. Preserving Legacy: Directing Lenin's Embalmers. MFA Thesis, U of Alberta.

Fischer-Lichte, Erika. 2008. The Transformative Power of Performance: A New Aesthetics. Translated by Saskya Iris Jain. New York: Routledge.

Foucault, Michel. 1990. "We Other Victorians." In A History of Sexuality, vol. 1: An Introduction, translated by Robert Hurley, 3-13. New York: Vintage.

Greenwood, Susan. 2013. "Magical Consciousness: A Legitimate Form of Knowledge." In Defining Magic: A Reader, edited by Bernd-Christina Otto and Michael Stausberg, 197-210. Sheffield, UK: Equinox.

Gustafson, Tom, dir. 2008. Were the World Mine. Performed by Tanner Cohen, Nathaniel David Becker, Wendy Robie, et al., SPEAKproductions. 
Huizinga, Johann. 2002. Homo Ludens: A Study of the Play-Element in [sic] Culture. 1949 translation. New York: Routledge.

Kill Your Television. 2018. Shakespeare's REJJ. Adapted by Joe Calarco.Theatre Network, The Roxy, Amiskwacîwâskahikan, Treaty 6/Métis Region 4, AB, 19 Jan.

Kobialka, Michal. 1999. "Introduction." In Of Borders and Thresholds: Theatre History, Practice, and Theory, edited by Kobialka, 1-29. Minneapolis: U of Minnesota P.

Marcus, Steven. 1966. The Other Victorians: A Study of Sexuality and Pornography in MidNineteenth-Century England. New York: Basic Books.

Muñoz, José. 1999. Disidentifications: Queers of Color and the Performance of Politics. Minneapolis: U of Minnesota P.

-. 2009. Cruising Utopia: The Then and There of Queer Futurity. New York: New York UP.

Nellhaus, Tobin et al. 2016. Theatre Histories: An Introduction. 3rd edition. New York: Routledge.

Padva, Gilad. 2014. Queer Nostalgia in Cinema and Pop Culture. New York: PalgraveMacMillan. Kindle.

Phelan, Peggy. 1993. Unmarked: The Politics of Performance. New York: Routledge.

Roach, Joseph. 1996. Cities of the Dead: Circum-Atlantic Performance. New York: Columbia UP.

Schechner, Richard. 2003. Performance Theory. Revised and expanded ed. New York: Routledge.

Schneider, Rebecca. 2011. Performing Remains: Art and War in Times of Theatrical Reenactment. New York: Routledge.

Shakespeare, William. 1977. “A Midsummer Night's Dream.” In The Portable Shakespeare, 397-465. New York: Penguin.

Taussig, Michael. 2011. I Swear I Saw This: Drawings in Fieldwork Notebooks, Namely My Own. Chicago: U of Chicago P.

Taylor, Diana. 2003. The Archive and the Repertoire: Performing Cultural Memory in the Americas. Durham: Duke UP.

Thiessen, Vern. 2010. Lenin's Embalmers. Toronto: Playwrights Canada Press. Drama Online, accessed 10 Feb. 2019. 
Turner, Victor. 1982. From Ritual to Theatre: The Human Seriousness of Play. New York: Performing Arts Journal Publications.

Weiss, Peter Eliot. 2018. Three Mysterious Women. Directed by Kathleen Weiss, performed by Tracy Penner, Gabby Bernard, and Melissa Thingelstad. StageLab Theatre Festival, Second Playing Space, U of Alberta, Amiskwacîwâskahikan, Treaty 6/Métis Region 4, AB, 23 Aug. 